\title{
SOME FACTORS AFFECTING THE MECHANICAL CHIPPING OF TREE-BRANCHES
}

\section{Ibrahim Yehia ${ }^{1}$ and Mohamed S. Omran ${ }^{2}$}

\begin{abstract}
The aim of this research is to study some factors affecting the mechanical chipping of tree-branches using a disc-chipper consists of frame, feeding duct, rotating disc with three knives, fixed knife in housing body, suction fan and $5.6 \mathrm{~kW}$ electric motor. The studied performance-factors are: cutting-knife speeds of 800, 1000, 1200, and $1400 \mathrm{rpm}$, clearances between rotating knives and disc of 10,15 and $20 \mathrm{~mm}$, tree-branch diameters of 30, 40, 50, $60 \mathrm{~mm}$ and random mixed and tree-branch moisture contents of 10, 15 and $20 \%$ in wet base. The main results of the tested disc-chipper were summarized in the following points: (1) The maximum average of cutting length is $25.5 \mathrm{~mm}$ was obtained with cuttingknives speed of $800 \mathrm{rpm}$, clearance of $20 \mathrm{~mm}$., tree-branches moisture content of $20 \%$ and tree-branches diameter of $30 \mathrm{~mm}$ Meanwhile, the minimum average of cutting length of $6.6 \mathrm{~mm}$ was obtained with cuttingknives speed of $1400 \mathrm{rpm}$, clearance of $10 \mathrm{~mm}$., tree-branches moisture content of $10 \%$ and mixed branch-diameters. (2) The maximum machineproductivity of $0.4 \mathrm{Mg} / \mathrm{h}$ was obtained with cutting-knives speed of 1400 rpm, clearance of $20 \mathrm{~mm}$., tree-branches moisture content of $20 \%$ and diameter of $60 \mathrm{~mm}$ Meanwhile, the minimum machine-productivity of 0.15 $\mathrm{Mg} / \mathrm{h}$ was obtained with cutting-knives speed of $800 \mathrm{rpm}$, clearance of 10 mm., tree-branches moisture content of $10 \%$ and mixed branchdiameters. (3) The maximum operation cost of 90.7 L.E./Mg was obtained by using tree branches diameter of $30 \mathrm{~mm}$ with moisture content of $10 \%$, clearance of $10 \mathrm{~mm}$ and at optimum knives-speed of $1400 \mathrm{rpm}$. Meanwhile, the minimum operation cost of 28.7 L.E./Mg was obtained by using tree-branches diameter of $60 \mathrm{~mm}$ with moisture content of $20 \%$, clearance of $20 \mathrm{~mm}$ at knives-speed of $1400 \mathrm{rpm}$.
\end{abstract}

\footnotetext{
$\overline{1}$ Professor and Previous Head of Mechanization Systems of Agric. Operations Dept, Agric. Eng., Res. Inst.

${ }^{2}$ Associated Prof., Agric. Eng. Dept., Fac., of Ag., Cairo Uni.
} 
The results showed that the tested disc-chipper can be used to chip residues of tree trimming which expand the area of its utilization for most farm residues through the year at the optimum knives-speed of $1400 \mathrm{rpm}$ which reduces the machine operating costs.

\section{INTRODUCTION}

7 he agricultural crop residues specially horticultures are considered one of the most important problems that face the environment and farmers in Egypt. The mechanical treatment is the primary step and suitable solution for using raw materials in several processes. FAO (2008) and Ghanem and Basiouny (2010) stated that there are many problems associated with agricultural waste.

These problems are the difficulty of decomposition due to higher content of cellulose materials, spreading of wastes over large areas which requires taking into consideration the assembly, transport and storage process, low specific density of the waste, which lead to a problem in the storage. Economic motives for the collection and transport are not available, containing rats and harmful insects, a good environment to ignite fires, and cause harmful environmental pollution when burned to humans, animals and field. The total quantity of agricultural residues in Egypt is about 79 million $\mathrm{Mg} / \mathrm{year}$. The quantity of palm, fruit and ornamental tree residues in year of 2014 are 4.3, 6.7 and 4.6million $\mathrm{Mg}$ respectively (B.C.A.A.E. S., 2015).

From a point of view, the tree-branches chopping is necessary as a pretreatment to different uses. Mechanical treatment of the tree-branches is done in order to convert it to small pieces, which are suitable for compost and energy briquetting, but the productivity of these choppers is still little, not covering the farmer needs in addition to the high operation and production cost are available in the market. Size reduction equipment was done by Woldt et al. (2004), and Miu et al. (2006), an extended layout of this classification and suggested hammermill, knife mill, and disc mill are the proper equipment for biomass comminution.

El-Iraqi and El-Khawaga (2003) designed and evaluated a machine for cutting crop residues. They found that the maximum percentage cuttinglength of rice straw less than $5 \mathrm{~cm}$ was $87.80 \%$ was investigated at using feeding rate of $0.771 \mathrm{Mg} / \mathrm{h}$ and cutting speed $10.09 \mathrm{~m} / \mathrm{s}$. Also, the energy 
requirement was $6.36 \mathrm{~kW} . \mathrm{h} / \mathrm{Mg}$. El-Fatih et al. (2010) modified and evaluated chopper for rice straw composting. They found that by increasing cutting-drum speed from $56.6 \mathrm{~m} / \mathrm{s}$ to $70.7 \mathrm{~m} / \mathrm{s}$. at concave-hole diameters $35 \mathrm{~mm}, 25 \mathrm{~mm}$ and $9 \mathrm{~mm} .:$ (1)The productivity increased from $489 \mathrm{~kg} / \mathrm{h}$ to $1150 \mathrm{~kg} / \mathrm{h}$, from $430 \mathrm{~kg} / \mathrm{h}$ to $976 \mathrm{~kg} / \mathrm{h}$ and from $350 \mathrm{~kg} / \mathrm{h}$ to $600 \mathrm{~kg} / \mathrm{h}$.(2) Consumed power increased from $2.15 \mathrm{~kW}$ to $3.4 \mathrm{~kW}$, from 3 $\mathrm{kW}$ to $4.2 \mathrm{~kW}$ and from $4.3 \mathrm{~kW}$ to $6.71 \mathrm{Kw}$. (3) The specific energy decreased from $4.4 \mathrm{~kW} . \mathrm{h} / \mathrm{Mg}$ to $2.96 \mathrm{~kW} . \mathrm{h} / \mathrm{Mg}$, from $6.98 \mathrm{~kW} . \mathrm{h} / \mathrm{Mg}$ to $4.3 \mathrm{~kW} . \mathrm{h} / \mathrm{Mg}$ and from $12.29 \mathrm{~kW} . \mathrm{h} / \mathrm{Mg}$ to $11.18 \mathrm{~kW} . \mathrm{h} / \mathrm{Mg}$ for $35 \mathrm{~mm}, 25$ $\mathrm{mm}$ and $9 \mathrm{~mm}$ respectively. Abo-Elasaad (2016) developed a rice-straw bales chopper. He found that the maximum values of power requirement and specific energy were $7.17 \mathrm{~kW}$ and $7.75 \mathrm{~kW}$. h/t which were obtained by using cutting-knives speed of $1260 \mathrm{rpm}$ and $750 \mathrm{rpm}$, platform tiltangle 30 degree and 24 cutting knives.

Mohamed (2016) developed a disc chipper and concluded that the optimum conditions of the developed disc chipper for rice straw were at cutting-knives speed of $1400 \mathrm{rpm}$. with moisture content of $14-26 \%$, clearance of 5-20 mm., average cutting length $7.1-23.6 \mathrm{~mm}$, machineproductivity $0.148-0.334-\mathrm{Mg} / \mathrm{h}$.

Spinelli et al. (2013) compared the effect of chipper type on productivity, power demand, fuel consumption and product quality. Tests were conducted on two commercial chipper models, a disc and a drum chipper. The disc chipper had a higher energy efficiency and used $19 \%$ less fuel per unit product. The drum chipper was $8 \%$ more productive, since it cut with the same energy all along the length of its knives. The drum chipper produced smaller chips, with a higher incidence of fines. Feedstock type had a strong effect on productivity, energy efficiency and product quality. The effect of feedstock type was mainly related to piece size, and may be stronger than the effect of chipper type.

\section{MATERIALS AND METHODS}

\subsection{Materials}

\subsubsection{The tested disc-chipper:}

The tested disc-chipper is shown in fig. (1). The disc-chipper consists of the following parts: 
- Frame: The overall length, width and height of the frame were 1200, 600 and $500 \mathrm{~mm}$ respectively.

- Feeding duct: The inlet and the internal openings and the depth of the feeding duct were $300 \times 400 \mathrm{~mm}, 130 \times 200 \mathrm{~mm}$ and $600 \mathrm{~mm}$, respectively.

- Cutting unit: The cutting-unit consists of the following parts: (1) The cutting housing has diameter of $430 \mathrm{~mm}$ and width of $400 \mathrm{~mm}$. (2) The cutting knives disc had diameter of $400 \mathrm{~mm}$, peripheral sluts with length of $150 \mathrm{~mm}$ and width of $45 \mathrm{~mm}$. Each slut has solid groove with depth of $5 \mathrm{~mm}$ (equal to knife thickness) and $30 \mathrm{~mm}$ width for knife support. (3) The three-rotating cutting-knives were made of alloy steel "K100" with $5 \mathrm{~mm}$ thickness, $40 \mathrm{~mm}$ width and 150 mm length.

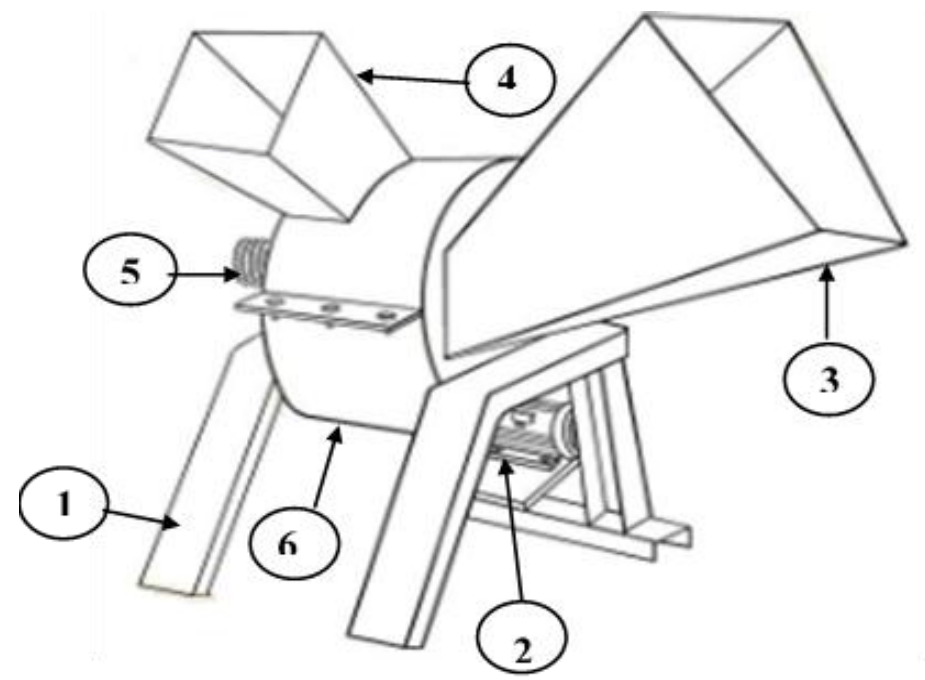

(1) Frame, (2) $5.6 \mathrm{~kW}$ electric motor, (3) Feeding duct, (4) Outlet duct, (5) Cutting and fan shaft (6) Cutting-knives disc and fan housing.

\section{Fig. 1. Sketch of the disc-chipper}

The rotating cutting-knives clearance can be adjusted by two nuts and bolts. The sketch of rotating disc, shaft rotating knives, fixed knife and suction fan assembly is shown in fig. 2. (4) The fixed knife was horizontally bolted with a plate. The plate has 3 sluts with width of 12 $\mathrm{mm}$ and length of $30 \mathrm{~mm}$. The sluts were used to adjust the constant 
distance between rotating and fixed knives after changing the tested clearances.

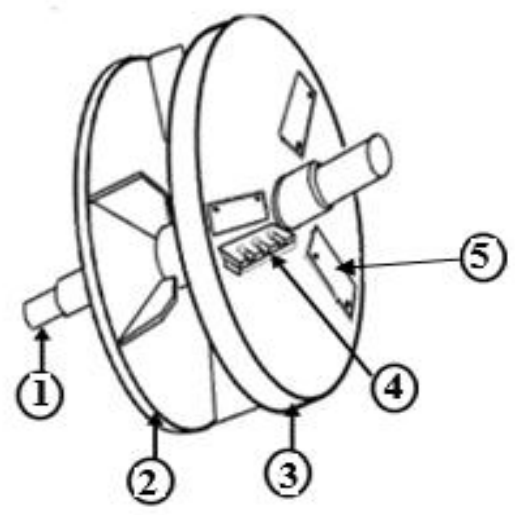

(1)Shaft, (2) Suction fan, (3) Rotating disc, (4) Fixed knife and (5) Rotating knife.

Fig. 2. Sketch of rotating disc and suction fan assembly

- Suction fan: Consists of a flange of $400 \mathrm{~mm}$ diameter, $6 \mathrm{~mm}$ thickness and 6 vanes with length of $140 \mathrm{~mm}$ and $4 \mathrm{~mm}$ thickness were welded on the flange. The gap between cutting-knives disc and the suction fan was $130 \mathrm{~mm}$.

- Outlet duct: The internal opening had dimensions of $150 \times 150 \mathrm{~mm}$, and the external opening had dimensions of $200 \times 200 \mathrm{~mm}$. The depth of outlet duct was $300 \mathrm{~mm}$.

- Electric motor: Electric-motor of $5.6 \mathrm{~kW}$ and $1800 \mathrm{rpm}$ was assembled with the frame to drive all rotating parts of the machine by means of pulleys and v-belts. The electric motor is equipped with the movable base using four bolts to be able to replace and change the tested pulleys.

- Power transmission-unit: Is showing in table (1).

Table 1. Tested motor, cutting shaft pulley diameters and cutting-knife and fan speeds.

\begin{tabular}{ccc}
\hline $\begin{array}{c}\text { Cutting-shaft pulley } \\
\text { diameter }(\mathbf{m m})\end{array}$ & $\begin{array}{c}\text { Motor-shaft pulley } \\
\text { diameter }(\mathbf{m m})\end{array}$ & $\begin{array}{c}\text { Cutting-knives and fan } \\
\text { speeds (rpm) }\end{array}$ \\
\hline & 89 & 800 \\
200 & 111 & 1000 \\
& 133 & 1200 \\
156 & 1400 \\
\hline
\end{tabular}




\subsubsection{Tree branches}

Apple, Olive and Ficus nitida tree-branches with average diameters of 30, 40, 50 and $60 \mathrm{~mm}$ and moisture contents of 10, 15 and $20 \%$ wet base were used in the experimental tests.

\subsection{Methods}

This study was performed in the workshops of Agricultural Engineering Research Institute (ARC) - Ministry of Agriculture - Dokki in 2017.

\section{(1) The studied parameters were:}

(a) Cutting-knives speeds: Preliminary tests were performed to select the appropriate chipping speed range, and reject the speeds which did not give enough torque to chipping tree-branches, and high speeds which caused block to the machine, the tested chipping-knife speeds were 800, 1000, 1200, and $1400 \mathrm{rpm}$.

(b) Clearances: The tested clearances between rotating knives and disc were 10,15 and $20 \mathrm{~mm}$.

(c) Tree-branches moisture contents: were 10, 15 and $20 \%$ in wet base.

(d) Tree-branch diameters: were 30, 40, 50 and $60 \mathrm{~mm}$.

\section{(2) Measurements:}

(a) Average cutting- length of tree-branches:

Average cutting-length for tree- branches which produced from disc chipper was measured from sample of $2.5 \mathrm{~kg}$ for each treatment by using Vernier caliper ( $0.1 \mathrm{~mm}$ accuracy).

(b) Machine productivity: was calculated using the following equation:

$\mathrm{P}=\mathrm{W} / \mathrm{t}$

Where:

$\mathrm{P}:$ Machine productivity $(\mathrm{kg} / \mathrm{h})$,

$\mathrm{W}$ : Mass of the chipped tree branches $(\mathrm{kg})$, and

$\mathrm{t}$ : Time (h).

(d) Power requirement and specific energy: The electrical power requirement $(\mathrm{kW})$ was calculated by using the clamp meter to measure the line current strength in Amperes (I) and potential 
difference values (v). The required power (P) was calculated according to Kurt, 1979 by using the following equation:

$\mathrm{P}=\sqrt{\mathbf{3}} \times \mathbf{I} \times \mathbf{V} \times \eta \times \operatorname{Cos} \theta / 1000$

Where:

P: Power requirement for the cutting machine in $\mathrm{kW}$,

I : Line current intensity in amperes,

$\mathrm{V}$ : Potential difference (Voltage) being equal to $380 \mathrm{~V}$,

$\operatorname{Cos} \theta:$ Power factor (being equal to 0.85 ),

$\sqrt{3}$ : Coefficient current three phase (being equal 1.73), and

$\eta$ : Mechanical efficiency assumed (95\%).

The specific energy was calculated by using the following equation:

Specific Energy $(\mathrm{kW} . \mathrm{h} / \mathrm{Mg})=\frac{\operatorname{Power}(\mathrm{kW})}{\operatorname{Productivity}\left(\frac{\mathrm{Mg}}{\mathrm{h}}\right)}$

(e) Operation costs: was calculated according to the equation given by Awady, 1978, in the following form:

$$
\mathrm{C}=\mathrm{p} / \mathrm{h}(1 / \mathrm{a}+\mathrm{i}+\mathrm{t} / 2+\mathrm{r})+(\mathrm{Ec} * \mathrm{Ep})+\mathrm{m} / 144
$$

Where:

C: hourly cost (LE/h),

P: price of machine (LE),

h: yearly working hours (h),

a: life expectancy of the machine (year),

i: interest (rate/year),

t: taxes (0.14),

r: overheads and indirect cost ratio (0.10),

Ec: Electricity consumption (kW.h),

Ep: Electricity price (LE/kW.h),

m: Monthly wage and "144" are estimated monthly working hours.

Notice that all units have to be consistent to result in (LE/h).

Production cost was

calculated according to the following equation:

Production cost $(L E / M g)=\frac{\text { operation cost }(\text { L.E. } / \mathrm{h})}{\text { Machine productivity }\left(\frac{\mathrm{Mg}}{\mathrm{h}}\right)}$ 


\section{RESULTS AND DISCUSSION}

\subsection{Effect of tested parameters on average of cutting-length}

Figs. 3 and 4 show the effect of cutting-knives speed, clearance, treebranches moisture content "M. C." and diameter on average of cutting length. The maximum average of cutting length of $25.5 \mathrm{~mm}$ was obtained with cutting-knives speed of $800 \mathrm{rpm}$, clearance of $20 \mathrm{~mm}$, tree-branches moisture content of $20 \%$ and diameter of $60 \mathrm{~mm}$. Meanwhile, the minimum average of cutting length of $6.6 \mathrm{~mm}$ was obtained with cuttingknives speed of $1400 \mathrm{rpm}$, clearance of $10 \mathrm{~mm}$, tree-branches moisture content of $10 \%$ and random mixed branch-diameters.

\subsection{Effect of cutting-knives speed}

Results show that by increasing cutting-knives speed from 800 to 1400 $\mathrm{rpm}$, the average of cutting length decreased by 7.16, 7.53, 7.51, 6.38 and $7.98 \%$ for branch diameters of 30, 40, 50, 60 and mixed respectively at all tested tree-branch moisture contents and clearances. The decreasing of average cutting-length of tree branches by increasing cutting-knives speed is due to increasing number of hits of cutting knives.

\subsection{Effect of tree-branches moisture content}

Results show that by increasing tree-branches moisture content from 10 to $20 \%$ the average of cutting length increase by 33.98, 21.97, 3.19, 2.7 and $19.19 \%$ for branch diameters of 30, 40, 50, 60 and mixed respectively at all tested cutting-knife speeds and clearances. The increasing of average cutting-length by increasing tree-branches moisture content is due to causing bending of tree branches, which face the knives disc.

\subsection{Effect of tree-branches diameter}

Data shows that by increasing tree-branches diameter from 30 to $60 \mathrm{~mm}$ the average of cutting length increased by $11.73 \%$ at all tested cuttingknife speeds, clearances and tree-branch moisture contents. The increasing of average cutting-length of tree branches by increasing treebranches diameter is due to increasing the cutting-slice diameter.

\subsection{Effect of clearance}

It was found that by increasing clearance from 10 to $20 \mathrm{~mm}$ the average of cutting length increased by 52.9, 57.94, 56.94, 50.84 and $57.95 \%$ for tree-branch diameters of 30,40, 50, 60 and mixed respectively at all tested speeds and tree-branch moisture contents. 

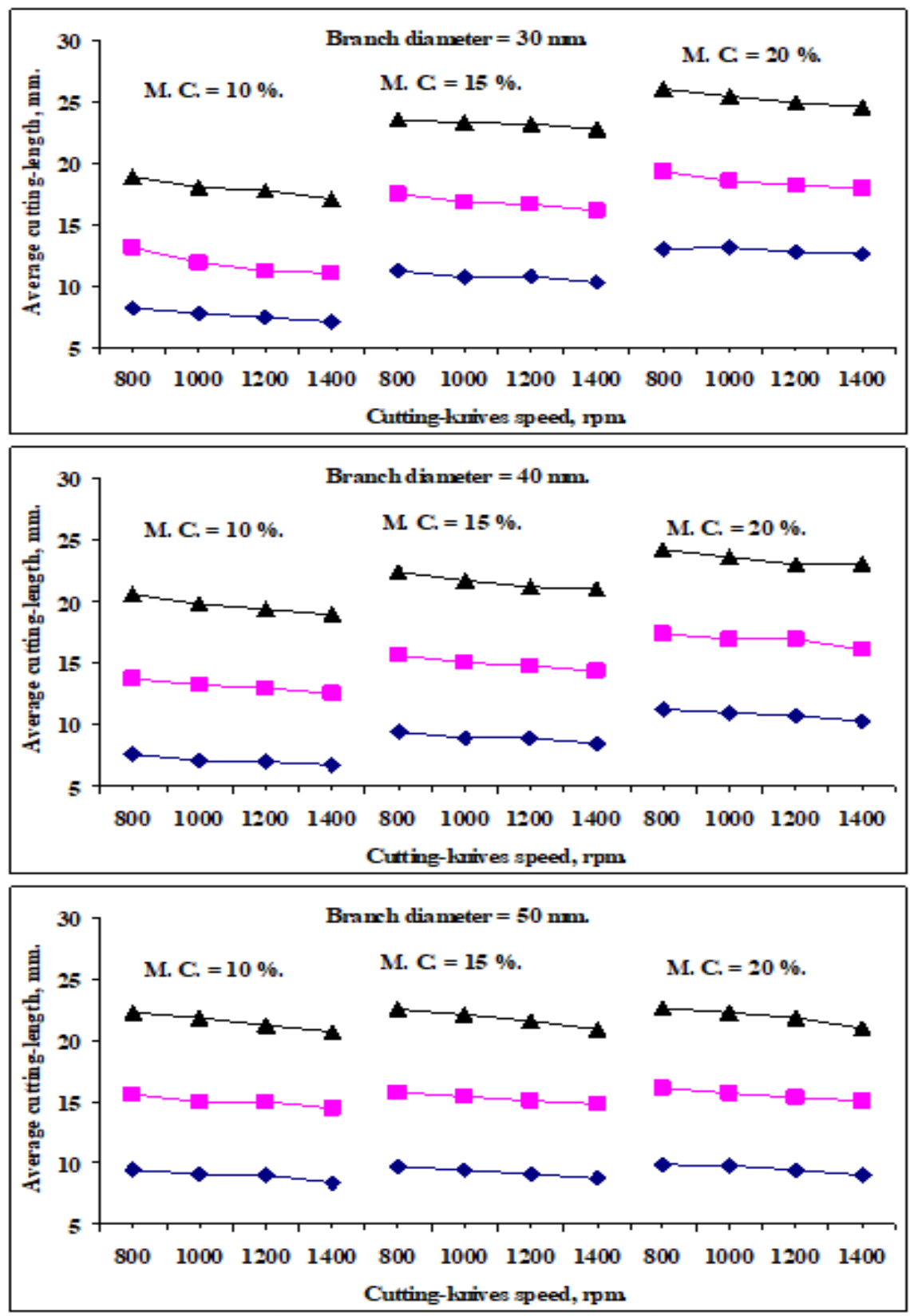

Clearance, $\mathrm{mm}$.

\section{$\neg-10-\mathbf{1 5} \leftarrow \mathbf{2 0}$}

Fig. 3. Effect of cutting-knives speed, clearance and tree-branches moisture content on average of cutting length for tree-branch diameters of 30,40 and $50 \mathrm{~mm}$. 

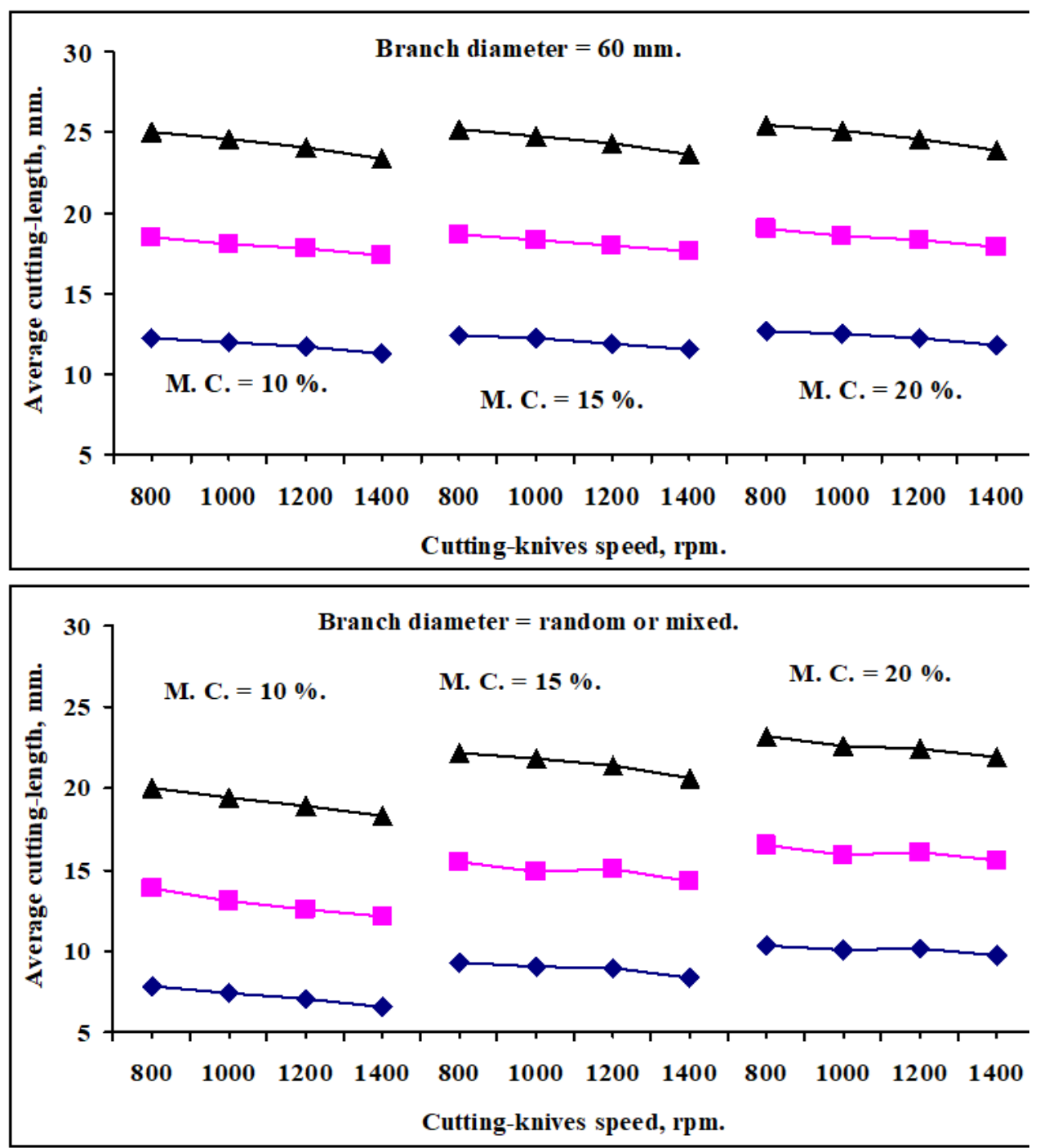

Clearance, $\mathrm{mm}$.

$$
-10-15-20
$$

Fig. 4. Effect of cutting-knives speed, clearance and tree-branches moisture content on average of cutting length for tree-branch diameters of 60 and random mixed

The increasing of average cutting-length of tree branches by increasing clearance is due to increasing spacing between rotating cutting-knives and disc. 
Factors affecting on the average of cutting length for tree branches under experiment and chipper conditions were combined into prediction regression-equation as follows:

$L_{C}=0.25 \frac{l c^{1.16} D b^{0.18} M C^{0.29}}{S^{0.14}}$

Where:

$\mathrm{R}^{2}=0.91$,

$\mathrm{L}_{\mathrm{c}}=$ Average of cutting length for tree branches, $\mathrm{mm}$,

$\mathrm{Db}=$ Tree-branches diameter, $\mathrm{mm}$ (ranged between $30-50 \mathrm{~mm}$ ),

$\mathrm{MC}=$ Moisture content of tree branches, \% (ranged between $10-20 \%$ ), and $\mathrm{S}=$ Chipping-knives speed, $\mathrm{m} / \mathrm{s}$ (ranged between $16.76-29.31 \mathrm{~m} / \mathrm{s}$ ).

\subsection{Effect of tested parameters on machine productivity}

Figs. 5 and 6 show the effect of cutting-knives speed, clearance and treebranches moisture content and diameter on machine productivity. Data shows that the maximum machine-productivity of $398.8 \mathrm{~kg} / \mathrm{h}$ was obtained with cutting-knives speed of $1400 \mathrm{rpm}$, clearance of $20 \mathrm{~mm}$., tree-branches moisture content of $20 \%$ and diameter of $60 \mathrm{~mm}$ Meanwhile, the minimum machine-productivity of $150.9 \mathrm{~kg} / \mathrm{h}$ was obtained with cutting-knives speed of $800 \mathrm{rpm}$, clearance of $10 \mathrm{~mm}$., treebranches moisture content of $10 \%$ and random mixed branch-diameters. Data shows that by increasing tree-branches moisture content from 10 to $20 \%$ the machine productivity increased by $21.96 \%$, by increasing knives speed from 800 to $1400 \mathrm{rpm}$ the machine productivity increased by 20. $9 \%$, by increasing clearance from 10 to $20 \mathrm{~mm}$, the machine productivity increased by 29.13 and by increasing tree-branches diameter from 30 to $60 \mathrm{~mm}$ the machine productivity increased by $44.15 \%$ at all tested parameters.

The increasing of machine productivity by increasing cutting-knives speed is due to decreasing of cutting time. Meanwhile, the increasing of machine productivity by increasing clearance and tree-branches moisture content is due to increasing the cutting-branches mass. 

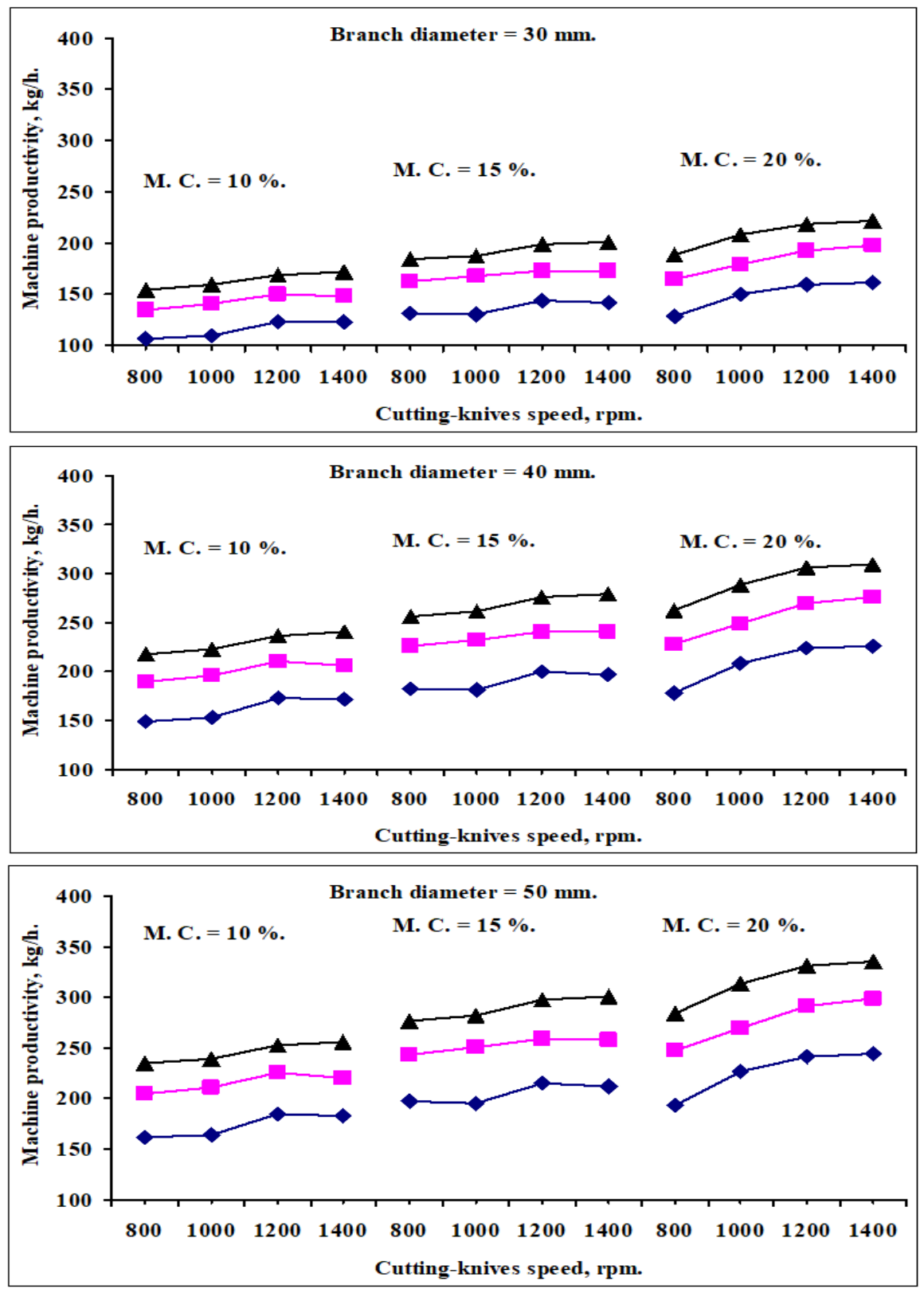

Clearance, $\mathrm{mm}$.

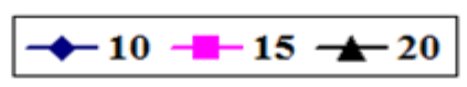

Fig. 5. Effect of cutting-knives speed, clearance and tree-branches moisture content on machine productivity for tree-branch diameters of 30 , 40 and $50 \mathrm{~mm}$. 

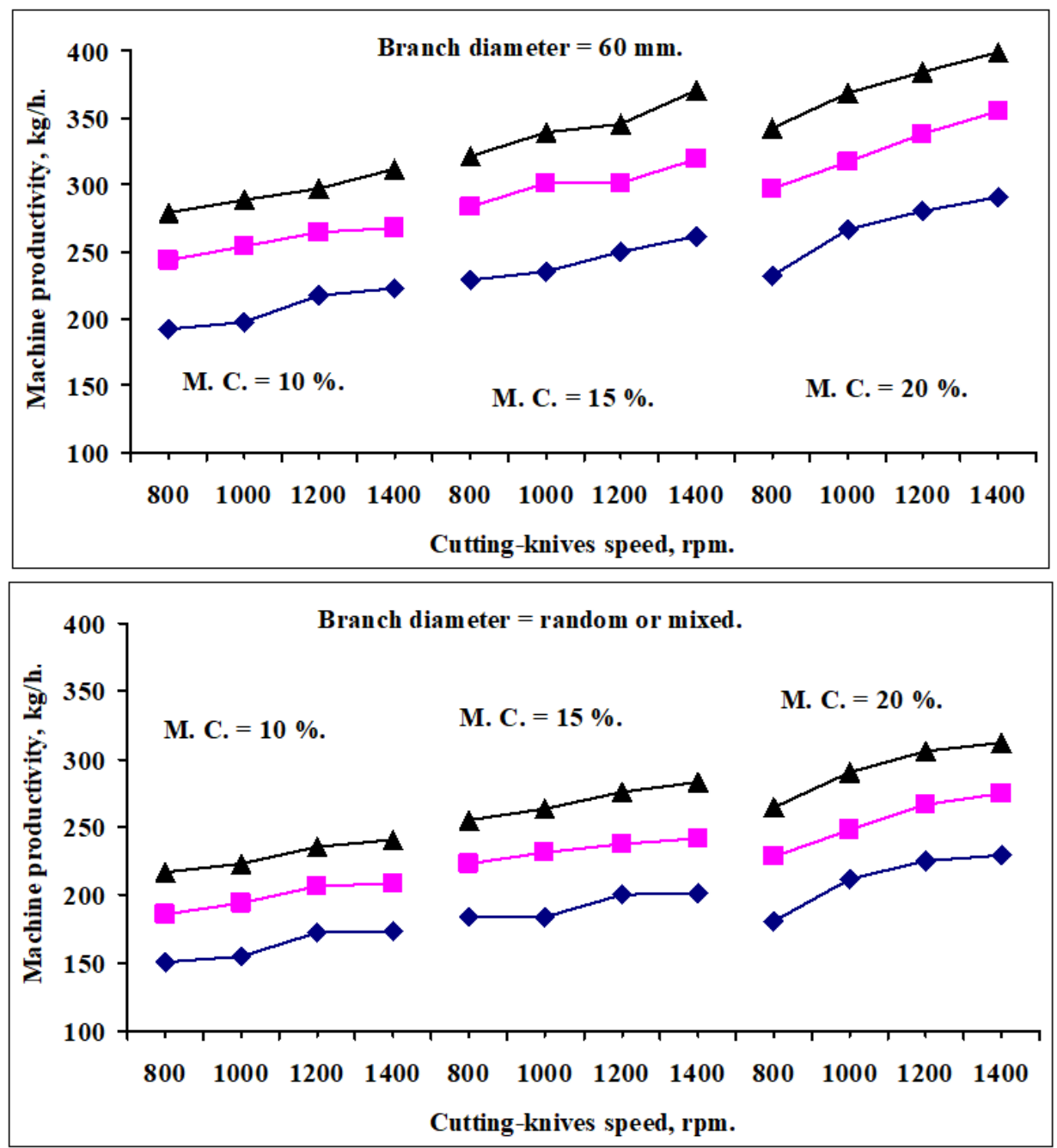

\section{Clearance, $\mathrm{mm}$.}

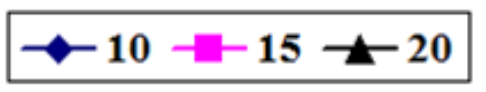

Fig. 6. Effect of cutting-knives speed, clearance and tree-branches moisture content on machine productivity for tree-branch diameters of 60 and random mixed.

Factors affecting chipping-machine productivity for tree-branches under experiment and chipper conditions were combined into prediction regression-equation as follows:

$\operatorname{Pr}=0.51 l c^{0.5} \mathrm{D}^{0.8} \mathrm{MC}^{0.36} \mathrm{~S}^{0.25}$ 
Where:

$\mathrm{R}^{2}=0.91$,

$\mathrm{L}_{\mathrm{c}}=$ Machine productivity, $\mathrm{kg} / \mathrm{h}$,

$\mathrm{D}_{\mathrm{b}}=$ Tree-branches diameter, $\mathrm{mm}$ (ranged between $30-50 \mathrm{~mm}$ ),

$\mathrm{MC}=$ Moisture content of tree branches, \% (ranged between 10-20\%) and $\mathrm{S}=$ Chipping-knives speed, $\mathrm{m} / \mathrm{s}$ (ranged between $16.76-29.31 \mathrm{~m} / \mathrm{s}$ ).

\subsection{Effect of tested parameters on power requirement}

Figs. 7 and 8 show the effect of test parameters on power requirement. Results show that the maximum power-requirement of $3.83 \mathrm{~kW}$ was obtained with cutting-knives speed of $1400 \mathrm{rpm}$, clearance of $10 \mathrm{~mm}$, tree-branches moisture content of $20 \%$ and diameter of $60 \mathrm{~mm}$ Meanwhile, the minimum power-requirement of $1.15 \mathrm{~kW}$ was obtained with cutting-knives speed of $800 \mathrm{rpm}$, clearance of $20 \mathrm{~mm}$, tree-branches moisture content of $10 \%$ and diameter of $30 \mathrm{~mm}$. It was found that by increasing tree-branches moisture content from 10 to $20 \%$ the power requirement increased by $25.23 \%$, by increasing knives speed from 800 to $1400 \mathrm{rpm}$ the power requirement increased by $31.05 \%$, by increasing clearance from 10 to $20 \mathrm{~mm}$ the power requirement decreased by 9.98 and by increasing tree-branches diameter from 30 to $60 \mathrm{~mm}$ the power requirement increased by $23.02 \%$ at all tested parameters.

Factors affecting power requirement for chipping tree branches under experiment and chipper conditions were combined into prediction regression-equation as follows:

$\mathrm{P}=0.03 \frac{D b^{0.40} M C^{0.42} S^{0.68}}{l c^{0.16}}$ \{valuable according to the experiment results

Where:

$\mathrm{R}^{2}=0.91$,

$\mathrm{P}=$ Power requirement $(\mathrm{kW})$,

$\mathrm{Db}=$ Tree-branches diameter $(\mathrm{mm})$,

$\mathrm{MC}=$ Moisture content of tree branches $(\%)$, and

$\mathrm{S}=$ Chipping-knives speed $(\mathrm{m} / \mathrm{s})$.

\subsection{Effect of tested parameters on specific energy}

Figs. 9 and 10 show the effect of cutting-knives speed, clearance and treebranches moisture content and diameter on specific energy. 

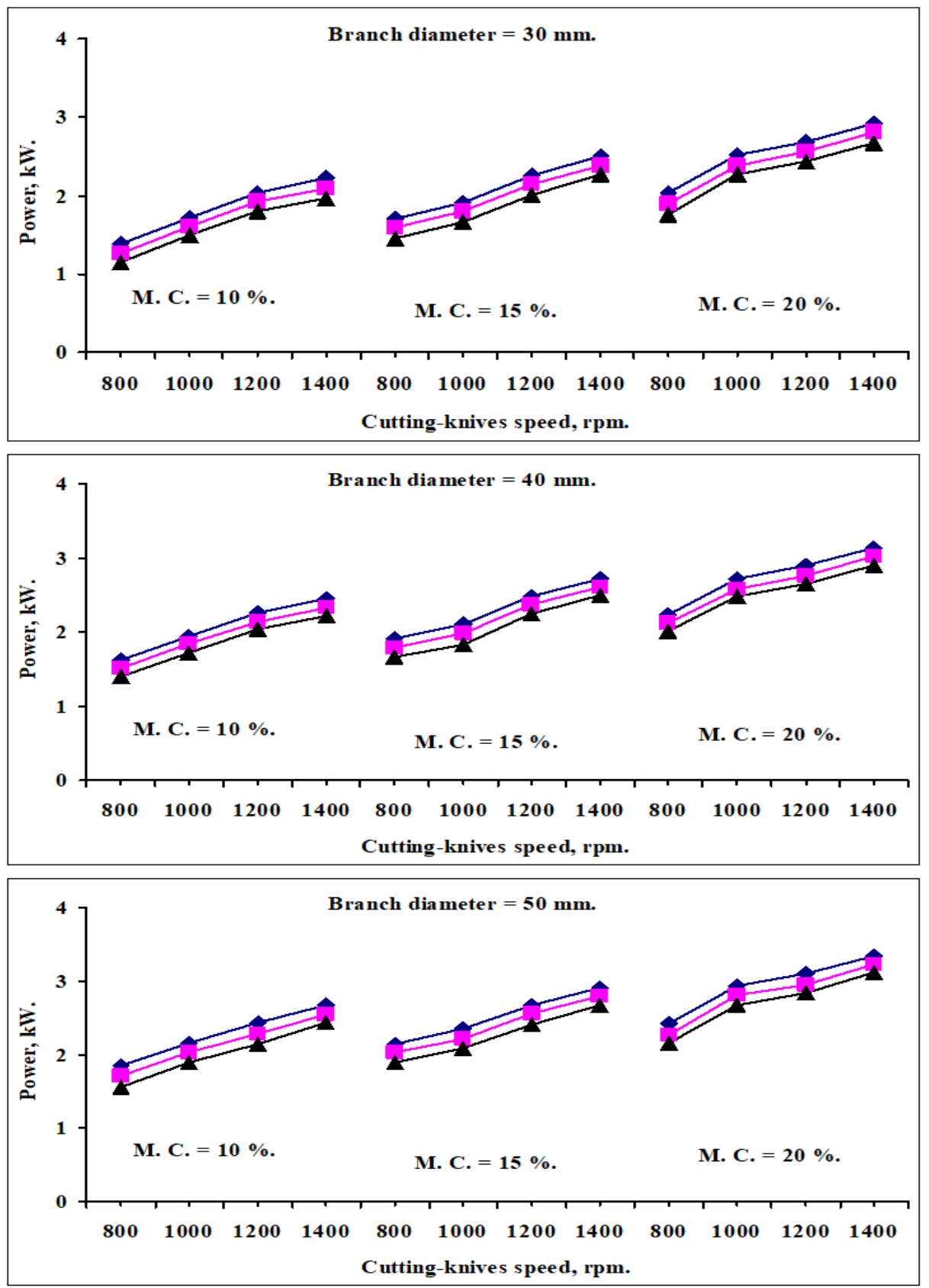

Clearance, $\mathrm{mm}$.

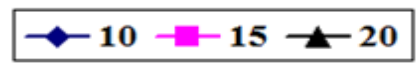

Fig. 7. Effect of cutting-knives speed, clearance and tree-branches moisture content on power requirement for tree-branch diameters of 30 , 40 and $50 \mathrm{~mm}$. 

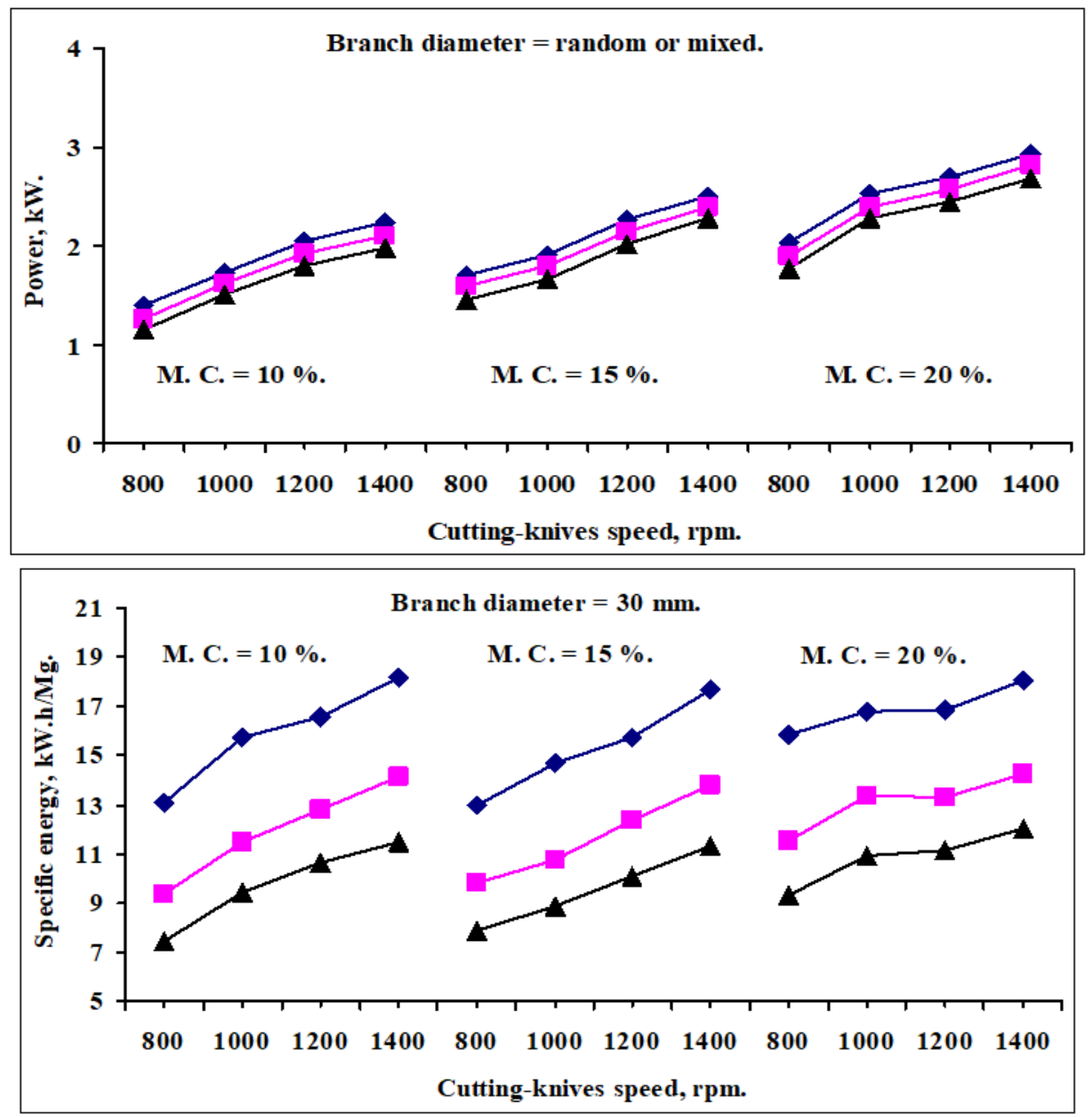

Clearance, $\mathrm{mm}$.

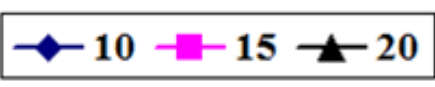

Fig. 8. Effect of cutting-knives speed, clearance and tree-branches moisture content on power requirement for tree-branch diameters of 60 and random mixed.

Results show that the maximum specific energy of $18.06 \mathrm{~kW} . \mathrm{h} / \mathrm{Mg}$ was obtained with cutting-knives speed of $1400 \mathrm{rpm}$, clearance of $10 \mathrm{~mm}$, tree-branches moisture content of $20 \%$ and diameter of $30 \mathrm{~mm}$ Meanwhile, the minimum specific energy of $6.43 \mathrm{~kW} . \mathrm{h} / \mathrm{Mg}$ was obtained with cutting-knives speed of $800 \mathrm{rpm}$, clearance of $20 \mathrm{~mm}$, tree-branches moisture content of $10 \%$ and diameter of $60 \mathrm{~mm}$. 
Results show that the optimum cutting-knives speed to chip tree branches by the tested disc-chipper was $1400 \mathrm{rpm}$. This is due to obtain the desirable and homogenous cutting length.
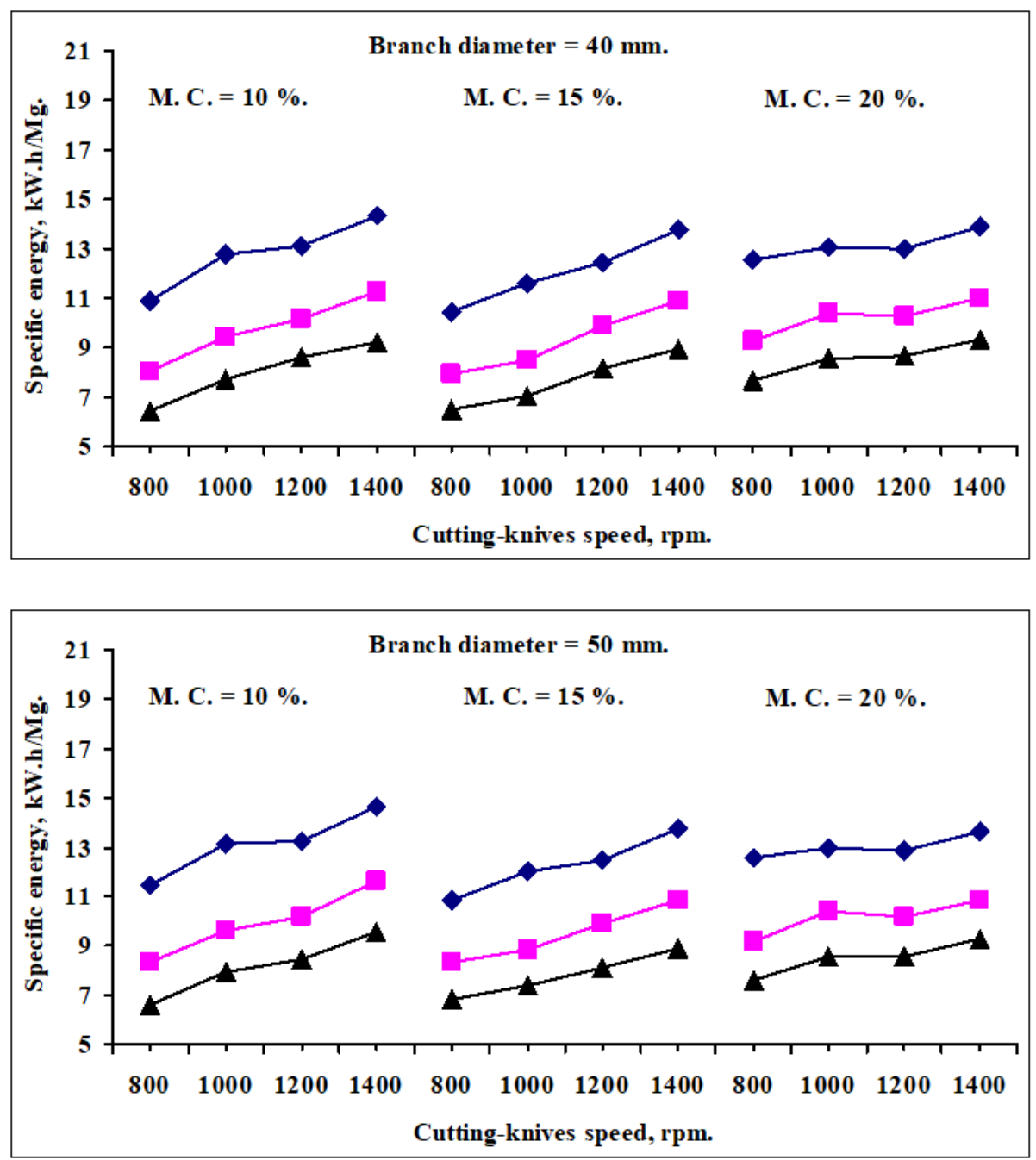

Clearance, $\mathrm{mm}$.

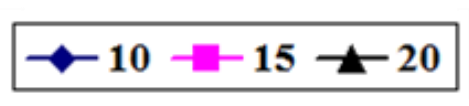

Fig. 9. Effect of cutting-knives speed, clearance and tree-branches moisture content on specific energy for tree-branch diameters of 30, 40 and $50 \mathrm{~mm}$. 

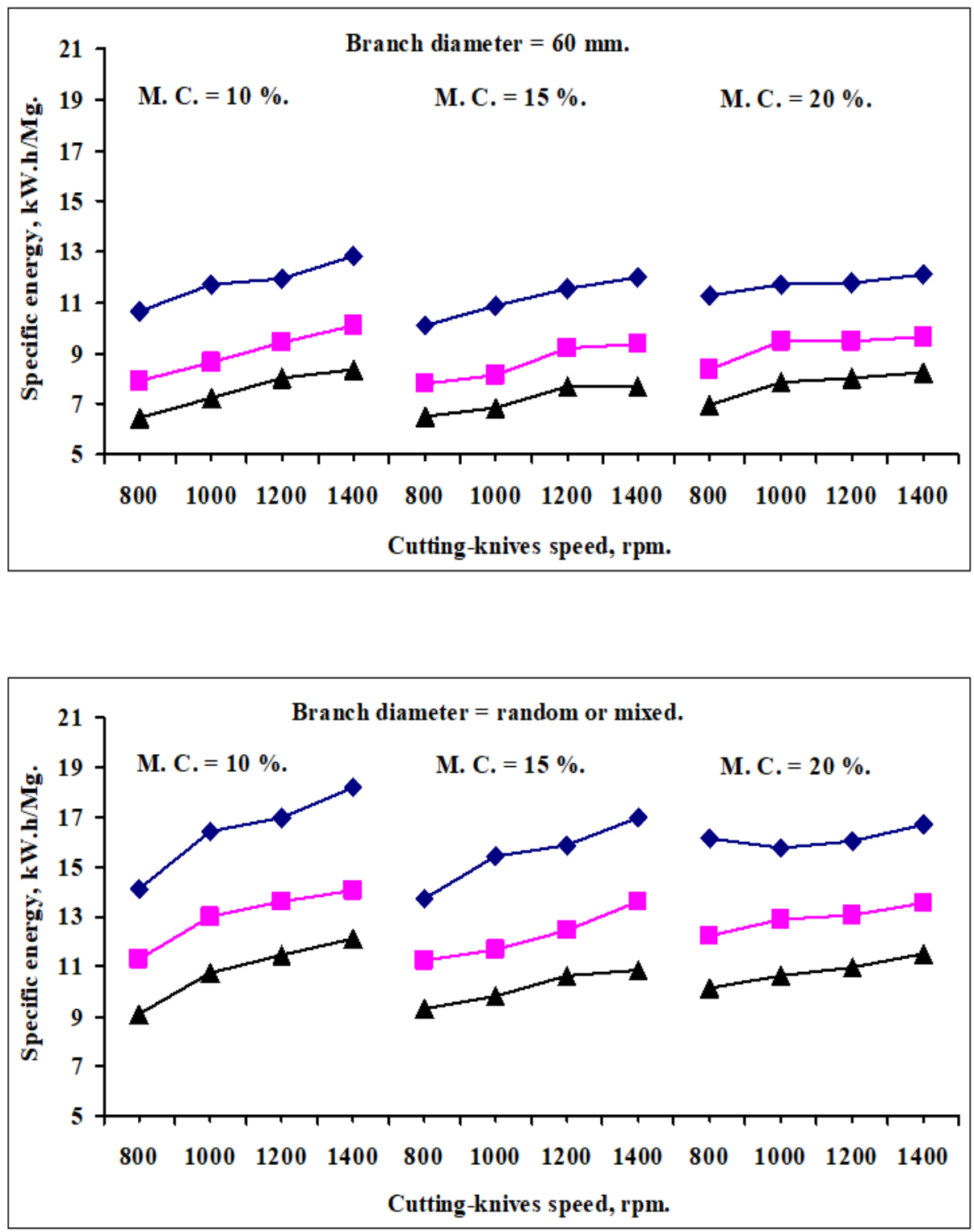

Clearance, mm.

\section{$10-15 \leftarrow 20$}

Fig. 10. Effect of cutting-knives speed, clearance and tree-branches moisture content on specific energy for tree-branch diameters of 60 and random mixed. 
Table 3. The effect of tree-branch diameter, moisture content, and clearance on operation and production costs at optimum cutting-knives speed of $1400 \mathrm{rpm}$.

\begin{tabular}{|c|c|c|c|c|c|c|c|c|c|c|c|c|c|}
\hline \multirow{3}{*}{$\begin{array}{l}\text { Moisture } \\
\text { content, } \\
(\%)\end{array}$} & \multirow{3}{*}{$\begin{array}{l}\text { Branch } \\
\text { Diameter } \\
(\mathbf{m m})\end{array}$} & \multirow{2}{*}{\multicolumn{3}{|c|}{$\begin{array}{c}\begin{array}{c}\text { Power requirement, } \\
(\mathrm{kW})\end{array} \\
\text { Clearance, } \mathbf{m m} .\end{array}$}} & \multicolumn{3}{|c|}{$\begin{array}{c}\text { Operation cost, } \\
(\mathrm{LE} / \mathrm{h})\end{array}$} & \multicolumn{3}{|c|}{$\begin{array}{c}\text { Machine productivity } \\
(\mathrm{kg} / \mathrm{h})\end{array}$} & \multicolumn{3}{|c|}{$\begin{array}{l}\text { Production cost, } \\
\text { (LE/Mg) }\end{array}$} \\
\hline & & & & & \multicolumn{3}{|c|}{ Clearance, mm. } & \multicolumn{3}{|c|}{ Clearance, mm. } & \multicolumn{3}{|c|}{ Clearance, mm. } \\
\hline & & 10 & 15 & 20 & 10 & 15 & 20 & 10 & 15 & 20 & 10 & 15 & 20 \\
\hline \multirow{5}{*}{10} & 30 & 2.23 & 2.09 & 1.97 & 11.1 & 11.1 & 11.0 & 122.7 & 147.9 & 171.9 & 90.7 & 75.0 & 64.3 \\
\hline & 40 & 2.46 & 2.33 & 2.22 & 11.2 & 11.2 & 11.1 & 171.4 & 206.5 & 240.1 & 65.3 & 54.0 & 46.3 \\
\hline & 50 & 2.67 & 2.55 & 2.44 & 11.3 & 11.2 & 11.2 & 182.4 & 219.7 & 255.5 & 61.7 & 51.1 & 43.8 \\
\hline & 60 & 2.85 & 2.71 & 2.6 & 11.3 & 11.3 & 11.2 & 222.4 & 267.9 & 311.5 & 50.9 & 42.1 & 36.1 \\
\hline & Mixed & 2.73 & 2.52 & 2.44 & 11.3 & 11.2 & 11.2 & 173.1 & 208.2 & 240.4 & 65.1 & 53.9 & 46.5 \\
\hline \multirow{5}{*}{15} & 30 & 2.5 & 2.38 & 2.27 & 11.2 & 11.2 & 11.1 & 141.3 & 172.3 & 200.3 & 79.3 & 64.8 & 55.6 \\
\hline & 40 & 2.72 & 2.61 & 2.5 & 11.3 & 11.2 & 11.2 & 197.0 & 240.3 & 279.4 & 57.2 & 46.8 & 40.1 \\
\hline & 50 & 2.91 & 2.8 & 2.68 & 11.3 & 11.3 & 11.3 & 211.9 & 258.4 & 300.4 & 53.5 & 43.7 & 37.5 \\
\hline & 60 & 3.13 & 2.99 & 2.85 & 11.4 & 11.4 & 11.3 & 261.5 & 319.0 & 370.9 & 43.6 & 35.6 & 30.5 \\
\hline & Mixed & 2.95 & 2.83 & 2.68 & 11.3 & 11.3 & 11.3 & 201.1 & 241.8 & 283.5 & 56.4 & 46.8 & 39.7 \\
\hline \multirow{5}{*}{20} & 30 & 2.92 & 2.81 & 2.67 & 11.3 & 11.3 & 11.3 & 161.7 & 197.2 & 221.6 & 70.1 & 57.3 & 50.8 \\
\hline & 40 & 3.14 & 3.03 & 2.9 & 11.4 & 11.4 & 11.3 & 226.1 & 275.8 & 309.9 & 50.4 & 41.2 & 36.6 \\
\hline & 50 & 3.34 & 3.23 & 3.12 & 11.5 & 11.4 & 11.4 & 244.5 & 298.1 & 335.0 & 46.9 & 38.3 & 34.0 \\
\hline & 60 & 3.53 & 3.42 & 3.28 & 11.5 & 11.5 & 11.4 & 291.0 & 354.9 & 398.8 & 39.6 & 32.4 & 28.7 \\
\hline & Mixed & 3.33 & 3.25 & 3.17 & 11.5 & 11.4 & 11.4 & 229.3 & 275.1 & 312.3 & 50.0 & 41.6 & 36.5 \\
\hline
\end{tabular}




\subsection{Effect of tested parameters on operation and production costs.}

Tables 2 and 3 show the components of the cost equation of using the disc-chipper for tree-branches at optimum cutting-knives speed of 1400 rpm.

Table 2. The components of cost equation.

\begin{tabular}{|c|c|c|c|c|c|c|c|c|}
\hline $\begin{array}{c}\mathrm{P} \\
(\mathrm{LE})\end{array}$ & $\begin{array}{c}\mathrm{h} \\
(\mathrm{h})\end{array}$ & $\begin{array}{c}\mathrm{a} \\
(\text { year })\end{array}$ & $\mathrm{i}$ & $\mathrm{t}$ & $\mathrm{r}$ & $\begin{array}{c}\mathrm{Ec} \\
(\mathrm{kW} . \mathrm{h})\end{array}$ & $\begin{array}{c}\mathrm{Ep} \\
(\mathrm{LE})\end{array}$ & $\begin{array}{c}\mathrm{m} \\
(\mathrm{LE})\end{array}$ \\
\hline 6000 & 3000 & 10 & 0.075 & 0.05 & 0.03 & $1.8-3.5$ & 0.30 & 1500 \\
\hline
\end{tabular}

Results show that the maximum operation cost of 3.53 L.E./h was obtained by using tree branches diameter of $60 \mathrm{~mm}$ with moisture content of $10 \%$, clearance of $10 \mathrm{~mm}$ and at optimum knives-speed of $1400 \mathrm{rpm}$. Meanwhile, the minimum operation cost of 1.97 L.E./h was obtained by using tree-branches diameter of $30 \mathrm{~mm}$ with moisture content of $20 \%$, clearance of $20 \mathrm{~mm}$ at optimum knives-speed of $1400 \mathrm{rpm}$.

Results show that the maximum production cost of 90.7 L.E./Mg was obtained by using tree branches diameter of $30 \mathrm{~mm}$ with moisture content of $10 \%$, clearance of $10 \mathrm{~mm}$ and at optimum knives-speed of $1400 \mathrm{rpm}$. Meanwhile, the minimum operation cost of 28.7 L.E./Mg was obtained by using tree-branches diameter of $60 \mathrm{~mm}$ with moisture content of $20 \%$, clearance of $20 \mathrm{~mm}$ at optimum knives-speed of $1400 \mathrm{rpm}$.

The production costs decreased by increasing clearance, tree-branch diameter and moisture content is due to increasing of machine productivity.

\section{CONCLUSION}

From the research results it concluded that the tested machine was useful for shipping tree-branches of different diameters, different speeds, multi moisture content and acceptable cost.

The optimum operation conditions of the disc-chipper to chip tree branches were: moisture content of $10-20 \%$, cutting-knives speed of $1400 \mathrm{rpm}$, and clearance of $10-20 \mathrm{~mm}$. The results obtained at optimum conditions were: average cutting-length $6.6-25.5 \mathrm{~mm}$, machineproductivity $150.9-398.8 \mathrm{~kg} / \mathrm{h}$, power-requirement $1.15-3.83 \mathrm{~kW}$, specific-energy $6.43-18.06 \mathrm{~kW} . \mathrm{h} / \mathrm{Mg}$ and costs of $1.97-3.53 \mathrm{LE} / \mathrm{h}$ and $28.7-90.7 \mathrm{LE} / \mathrm{Mg}$. 


\section{REFFERENCES}

Abo-Elasaad, G. A. 2016. Development of a rice straw bales chopper. M. Sc. Dept. of Agic. Mech. Fac. of Agriculture. Mansoura Univ.: 47 79.

Awady, M. N. 1978. Tractors and Farm Machines. Fac. Agric. Ain Shams Univ. 164-167.(Arabic text)

B.C.A.A.E.S. (Bulletin of Central Administration for Agricultural Extension Service) 2015, Ministry of Agric., Egypt. (in Arabic).

EL-Eraqi, M. and S. EL-Khawaga. 2003. Design and test performance of cutting machine for some crop residues. (a). Misr J. Agric. Eng., 20(1): $85-101$.

El-Fatih, A.; E. M. Arif and A. E. Atef, 2010, Evaluate the Modified Chopper for Rice Straw Composting. J. Appl. Sci. Res., 6(8): 1125 1131.

FAO, 2008, Animal production based on crop residues processing machines, Corporate Document, Repository, Agric. and Consumer Protection.

Ghanem, G. H. and Basiouny, M. A., 2010, Modifying a thresher for ensiling the green rice straw by shredding, Misr J. Agric. Eng., 27(2): 482-500.

Kurt, G., 1979. Engineering formulas, $3^{\text {rd }}$ Ed., McGraw Hill Book N. Y.

Miu, P. I, R. Alvin; A. R. Womac; I. Cannayen, and S. Sokhansanj, 2006. Analysis of biomass comminution and separation processes in rotary equipment - a review, ASABE Ann. Int. Mtg Sponsored by ASABE Oregon Convention Center, Portland, Oregon, and Mich.

Mohamed. A. H. 2016. Development of a rice straw disc chipper, J. Soil Sci. and Agric. Eng. Mansoura Univ. 7 (10): 705 - 711.

Spinelli R., E. Cavallo, L. Eliasson, A. Facello. 2013. Comparing the efficiency of drum and disc chippers. Silva Fennica. 47(2):1-11.

Woldt, D. ; G. Schubert and H. G. Jäckel. 2004. Size reduction by means of low-speed rotary shears. Int. J. of Mineral Proc. 74: 405-415 


\section{الملخص العربى}

\section{بعض العوامل المؤثرة على التقطيع الميكانيكى لأفرع الأثجار

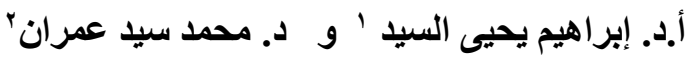

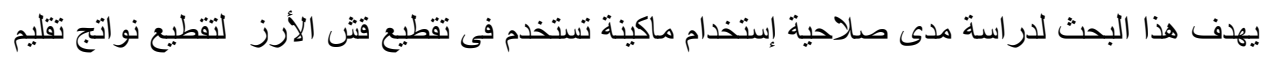

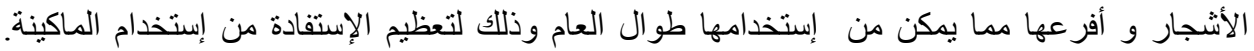

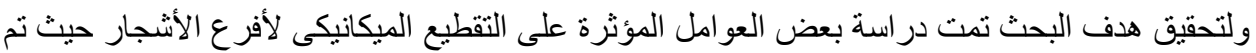

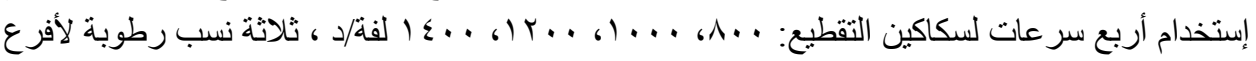

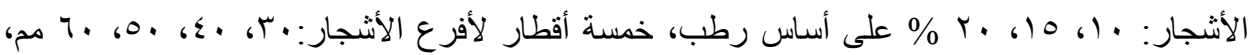

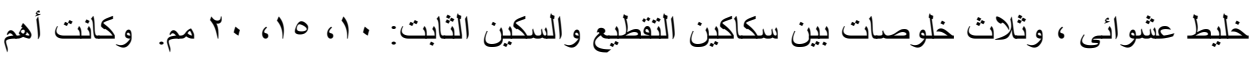

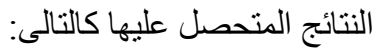

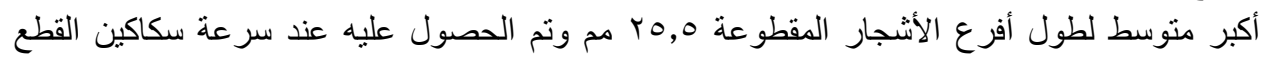

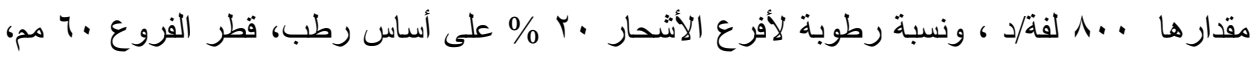

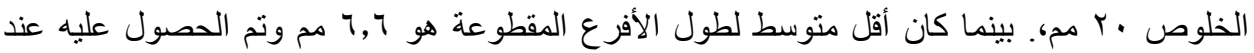

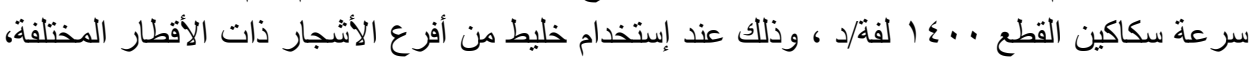

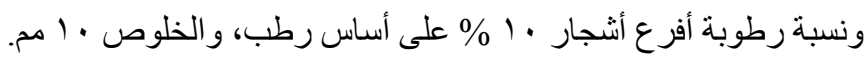

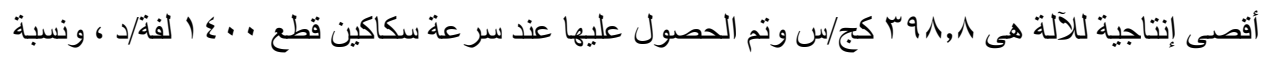

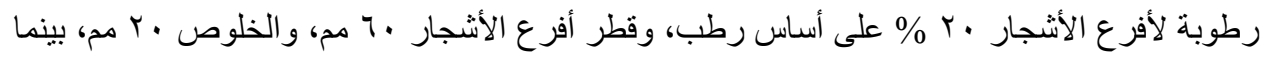

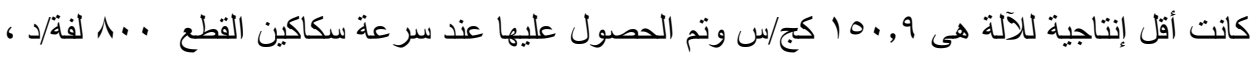
ونسبة رطوبة أفرع الأثجار ل 1 \% على أساس رطب، وخليط من أفرع الأشجار ذات الأقطار المختلفة،

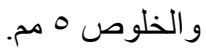

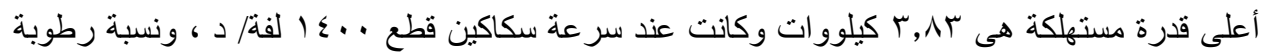

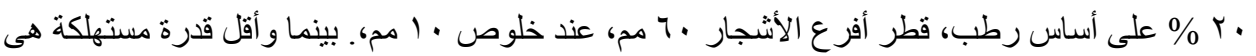

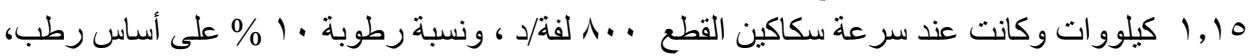

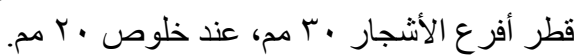

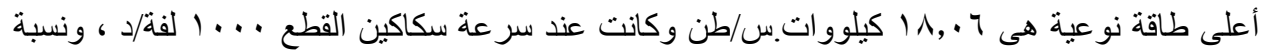

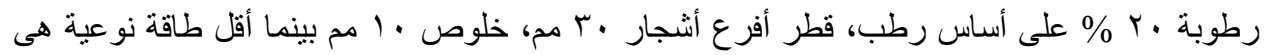

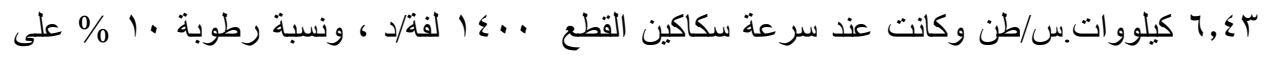

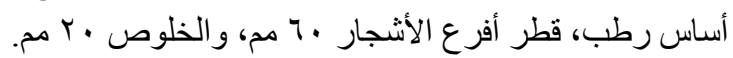

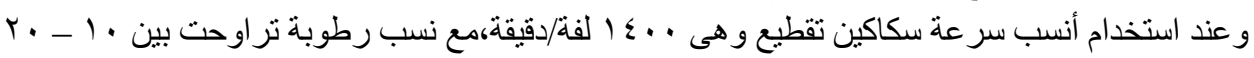

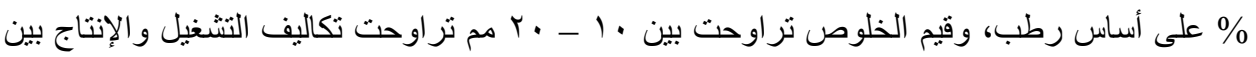

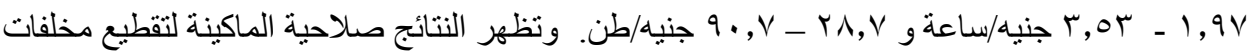

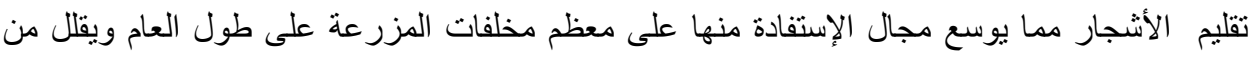

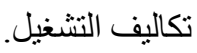

' رئيس بحوث ورئيس قسم نظم ميكنة العمليات الزراعية العابق، معهل بحوث الهندة الزراعيةـ مركز

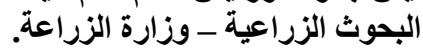
† † أستاذ الهندسة الزراعية المساعد، قسم الهنسة الزراعية، كلية الزراعة، جامعة القاهرة. 